\title{
Determining environmental risk and source of heavy metal(loid)s in the surrounding farmland soil of a zinc smelter in water source area, Northwest China
}

Xinwei Lu ( $\square$ luxinwei@snnu.edu.cn )

Shaanxi Normal University

Sukai Zhuang

Shaanxi Normal University

\section{Research Article}

Keywords: Heavy metal(loid)s, Soil, Risk assessment, Principal component analysis, Correlation analysis, Zinc smelter

Posted Date: April 6th, 2021

DOI: https://doi.org/10.21203/rs.3.rs-332869/v1

License: (c) (i) This work is licensed under a Creative Commons Attribution 4.0 International License.

Read Full License 


\section{Abstract}

Risk and source of heavy metal(loid)s ( $\mathrm{As}, \mathrm{Cu}, \mathrm{Cr}, \mathrm{Pb}, \mathrm{Mn}, \mathrm{Ni}, \mathrm{V}$, and $\mathrm{Zn}$ ) were determined in the surrounding farmland soil of a zinc smelter in the water source area of the Mid-route of South-North Water Transfer Project of China to explore the impact of smelting activity on local environment. The heavy metal(loid)s contents were analyzed by $X$-ray fluorescence spectrometry and their pollution levels and ecological risks were assessed by geoaccumulation index, Nemerow synthetic pollution index and potential ecological risk index. The possible sources of the heavy metals(loid)s were identified by multivariate statistical analysis methods. The mean contents of the heavy metal(loid)s in the farmland soil were above the local soil background values except $\mathrm{Mn}$. The contents of $\mathrm{As}, \mathrm{Cu}, \mathrm{Pb}, \mathrm{Zn}$, and $\mathrm{Ni}$ in the downwind direction soil decreased with the distance increasing between the sampling site and the zinc smelter. The investigated soils were moderately to seriously polluted by heavy metal(loid)s and the heavy metal(loid)s presented moderately ecological risk as a whole. $\mathrm{As}, \mathrm{Cu}, \mathrm{Pb}$, and $\mathrm{Zn}$ mainly originated from zinc smelting activities. $\mathrm{Cr}, \mathrm{Mn}$, and $\mathrm{V}$ primarily derived from natural source. Ni mainly came from zinc smelting activities, partly from natural source. The zinc-smelting activity influenced the heavy metal(loid)s content, particularly $\mathrm{Zn}$ and $\mathrm{Pb}$, in the surrounding farmland soil. The local government should strengthen the cooperative monitoring of heavy metal(loid)s in farmland and agricultural products, as well as pollutant emission monitoring and control.

\section{Introduction}

With the development of industry, the acceleration of urbanization, and the increase of agricultural chemicals using, soil pollution problems have become increasingly prominent and attract more and more attention worldwide in recent decades (Zhao et al. 2020; Kumar et al. 2019; Zhang et al. 2019; Akopyan et al. 2018; Yang et al. 2018; Li et al. 2017 ). Among all kinds of soil pollutants, heavy metal(loid)s cause more attention due to their high toxicity and non-biodegradability (Wu et al. 2020). Heavy metal(loid)s in soil can be absorbed and enriched in plants and transferred to animals and human bodies via food chains (Liu et al. 2017; Zhang et al. 2016). When people eat grains or vegetables polluted by heavy metal(loid)s, their survival and health will be threatened (Baltas et al. 2020; Zhou et al. 2020; Bhatti et al. 2018; Li et al. 2019, 2018). High contents of heavy metal(loid)s in the body can interfere with the physiological process of the body, and injure human organs such as heart, bone, kidney, small intestine, reproductive system and nervous system (Csavina et al. 2012). Hence studying and evaluating the ecological risk of heavy metal(loid)s in farmland are important for understanding soil environmental quality, strengthening comprehensive prevention of soil pollution and safeguarding human health.

The major sources of soil heavy metal(loid)s are natural sources and anthropogenic sources (Jiang and Guo 2019). Weathering of rocks, volcanic eruptions, splashing waves, vegetation discharge are the main natural sources (Lee et al. 2020). While mining, beneficiation, metal smelting, electroplating, dyes, textiles, burning of fossil fuels, agricultural pesticides, fertilizers, sludge application and sewage irrigation are the main anthropogenic sources (Wang et al. 2019; Peng et al. 2019; Ettler 2016; Lu et al. 2014a). Among various soil heavy metal(loid) sources, nonferrous metal smelting is one of the significant (Kang et al. 
2019; Kríbek et al. 2019; Ghayoraneh and Qishlaqi 2017; Shiel et al. 2010; Wang et al. 2010). In the metal smelting process, large quantities of heavy metal(loid)s discharge into surrounding soil through sewage irrigation, waste residue infiltration and atmospheric sedimentation, resulting in heavy metal(loid)s pollution in farmland soil around smelter (Shen et al. 2017; Wen et al. 2015). These metals cannot be degraded naturally in soil, but through continuous enrichment in the soil to achieve a high level. Many studies have shown that contaminated soils around smelters have become high-risk areas for safe production of agricultural products (e.g. Lee et al. 2020). There are lots of literatures on soil heavy metal(loid)s pollution around smelters in China, but most of which are concentrated in the eastern and southern areas of the country (e.g. Zhao et al. 2020; Li et al. 2018; 2011). Whereas, up to now, few researches on farmland soil pollution around metal smelters have been launched in the water source area of the Mid-route of South-North Water Transfer Project.

Shangluo city $\left(33^{\circ} 2^{\prime} 30^{\prime \prime}-34^{\circ} 24^{\prime} 40^{\prime \prime} \mathrm{N}, 108^{\circ} 34^{\prime} 20^{\prime \prime}-111^{\circ} 1^{\prime} 25^{\prime \prime} \mathrm{E}\right)$ is located in the upstream of Danjiang valley, the water source area of Mid-route South-North Water Transfer Project of China (Zhuang and Lu 2020). With abound non-ferrous metal resources, such as zinc, lead, copper, molybdenum and gold, Shangluo is the important mineral resources base in Northwest China. Many metal mining and smelting industries are distributed in Shangluo, which may cause heavy metal(loid)s pollution in agricultural soil and water. Heavy metal(loid)s in agricultural soil would enter into surface water with runoff or soil erosion excepting pollute agricultural products, leading to the deterioration of water quality. South-North Water Transfer Project is a national water resource allocation project for solving the water shortage in North China. Water security is crucial to South-North Water Transfer Project. Shangluo has abundant rainfall and complex topography and geomorphology, which result in serious soil erosion in that area.

To understand the impact of metal smelting activities to farmland soil in the water source area, the farmland around a zinc-smelting plant with no other large-scale anthropogenic source in its vicinity in Shangluo, Northwest China was investigated in this study. The primary purposes of this study are (1) to determine the contents of heavy metal(loid)s in the farmland soil around the zinc smelter; (2) to evaluate the contamination degrees and ecological risks of the investigated heavy metal(loid)s in the farmland soil; and (3) to identify the sources of heavy metal(loid)s in the farmland soil. The findings of this study would help us to understand the impact of metal-smelting activities on the environment of the water source area and would offer the basic information for regulators in environmental protection of the water source area.

\section{Materials And Methods}

\section{Study area}

Shangluo is a mountainous valley city with a permanent population of 2.50 million (up the end of 2019) about $110 \mathrm{~km}$ southeast of the provincial capital Xi'an. The climate of Shangluo is semi-humid monsoon mountain climate in warm temperate zone. January is the coldest month with a mean temperature of $7.8^{\circ} \mathrm{C}$ while July is the hottest with a mean temperature of $13.9^{\circ} \mathrm{C}$. The annual mean 
precipitation is $696.8-830.1 \mathrm{~mm}$. Affected by the terrain, the annual wind direction in Danjiang valley is mainly east (E), east-south-east (ESE), and west (W), and the mean wind speed is circa $2.4 \mathrm{~m} \mathrm{~s}^{-1}$. The main crops in Shangluo are wheat and corn, and the main cash crops are vegetables and walnuts.

The investigated zinc smelter, located at the hillside of the north bank of Danjing valley about $7 \mathrm{~km}$ southeast of Shangluo city, was built in 1987 with 50 thousand tons of zinc productivity per year. Meanwhile, precious metals such as silver ( $\mathrm{Ag}$ ) and indium (In) are recovered and produced in the zinc smelting process. The main raw ore of the zinc smelter is sphalerite ( $\mathrm{ZnS})$, associated galena $(\mathrm{PbS})$ and chalcopyrite $\left(\mathrm{CuFeS}_{2}\right)$. In addition, it also contains cadmium, indium, silver and other metals.

Considering the influence of topography, wind direction and villages distribution, three plots of farmland (marked A, B and C, respectively) in different directions near the smelter were selected for soil sampling (Fig. 1). Plot $A$ is located on the hillside in the northwest direction of the zinc smelter. There are no villages near this plot and the traffic is inconvenient as only farmland paths lead to there. The altitude of the terraced farmland on the hillside is about 700-720 m and about tens of meters higher than the smelter. Plot $B$ is located in the southwest of the smelter and next to a village. The altitude of plot $B$ is about 647-649 $\mathrm{m}$ which is lower than that of the smelter. There are hardened rural cement roads around Plot B. Luxuriant trees and shrubs grow on the hillsides between plot $B$ and the smelter. Plot $C$ is located in a valley to the east of the smelter and a small seasonal stream flows through the valley. The altitude of plot $C$ is about $680-690 \mathrm{~m}$ which is slightly lower than that of the smelter. There is barely vegetation between plot $C$ and the smelter. All three plots are wheat and corn rotation, and grains grown on the farmland are consumed by the local residents. The soil type of the investigated farmland is yellowbrown soil with a pH from 7.2 to 8.3. The mean value of soil organic matter, total nitrogen, total phosphorus, available nitrogen, available phosphorus and available potassium was $20.1 \mathrm{~g} \mathrm{~kg}^{-1}, 1.2 \mathrm{~g} \mathrm{~kg}^{-}$ $1,0.6 \mathrm{~g} \mathrm{~kg}^{-1}, 108.9 \mathrm{mg} \mathrm{kg}^{-1}, 17.9 \mathrm{mg} \mathrm{kg}^{-1}$ and $113.7 \mathrm{mg} \mathrm{kg}^{-1}$, respectively. Texture analysis indicates that soil is silty clay loam, composed of sand (26.3\%), silt (56.0\%), and clay $(17.7 \%)$. The mean contents of major elements, i.e. $\mathrm{Fe}_{2} \mathrm{O}_{3}, \mathrm{CaO}, \mathrm{K}_{2} \mathrm{O}, \mathrm{MgO}, \mathrm{Na}_{2} \mathrm{O}, \mathrm{SiO}_{2}$, and $\mathrm{Al}_{2} \mathrm{O}_{3}$ were $6.7 \%, 0.9 \%, 1.5 \%, 1.8 \%, 2.0 \%$, $33.1 \%$, and $7.8 \%$, respectively.

\section{Sampling and analytical methods}

Soil samples were collected in July 2017. A hand-held GPS was used to record the longitude, latitude, altitude and other information of sampling location. A total of 25 topsoil $(0-20 \mathrm{~cm})$ samples were taken from plot $A$ (9 samples, numbered $A 1-A 9)$, plot $B$ (8 samples, numbered $B 1-B 8$ ) and plot $C$ (8 samples, numbered $\mathrm{C} 1-\mathrm{C} 8$ ) (Fig. 1). At each point, a composite soil sample was fully mixed and retained at $1 \mathrm{~kg}$ in accordance with the four-point method in an area of about $2 \mathrm{~m} \times 2 \mathrm{~m}$. All soil samples were kept in polythene bags.

In the laboratory, all soils were air-dried naturally, and then the impurities were removed. Agate mortar and pestle were used to ground the samples to pass through $75 \mu \mathrm{m}$ nylon mesh. The processed samples were stored in polyethylene plastic bags. Preventing from the cross-contamination between different 
samples, all processing was performed avoiding touching with metallic object. $4 \mathrm{~g}$ of treated soil and about $2 \mathrm{~g}$ of boric acid which used as the substrate were pressed by the molding press to form a circular sheet sample to be tested (Chen et al. 2013). The contents of heavy metal(loid)s (As, Cu, $\mathrm{Cr}, \mathrm{Pb}, \mathrm{Mn}, \mathrm{Ni}, \mathrm{V}$, and Zn) in soil were tested using X-ray fluorescence spectrometer (XRF, Panalytical, PW2403) according to the method in literature (Pan et al. 2017). The national standard material samples and parallel samples were adopted for quality guarantee and control in the experiment. Relative error between the detected value and reference value of elements in standard sample is less than $10 \%$, and that of the duplicate sample is less than $5 \%$.

\section{Assessing methods of pollution and ecological risk}

The geoaccumlation index $\left(I_{\text {geo }}\right)$ and Nemerow synthetic pollution index (NSP) were respectively used to assess the single pollution level and comprehensive pollution level of heavy metal(loid)s in the farmland soil. The $I_{\text {geo }}$ is calculated using the following formula (Zhang et al. 2019; Chakraborty et al. 2017; Duodu et al. 2016)

$$
I_{\mathrm{geo}}=\log _{2} \frac{C_{i}}{\mathrm{k} \times B_{i}}
$$

where $C_{i}$ is the content of heavy metal(loid) $i$ in the soil $\left(\mathrm{mg} \mathrm{kg}^{-1}\right)$; constant $\mathrm{k}$ is a change in reference value that may be caused by diagenesis, here 1.5 was accessed; $B_{i}$ refers to the reference value of heavy metal(loid) $i$ in parent rock, here refers to the soil element background value of Shaanxi (CNEMC 1990). The grades of pollution were distinguished in 6 levels proposed by Müller (1969) (Table S1 in Supplementary Materials).

The NSP/ is calculated by formula (2) (Zhang et al. 2019)

$$
N S P I=\sqrt{\frac{P_{\text {iave }}^{2}+P_{\text {imax }}^{2}}{2}}
$$

where $P_{\text {iave }}$ and $P_{\text {imax }}$ respectively represents the mean and the maximum of single pollution index $P_{i}$ of all heavy metal(loid)s in a sample. $P_{i}$ is equal to the ratio of the content of heavy metal(loid) $i$ in the farmland soil and its corresponding background value in Shaanxi soil. The grades of $P_{i}$ and $N S P I$, as well as the corresponding pollution levels are listed in Table S2 and Table S3 (Supplementary Materials).

Potential ecological risk index (PERl), proposed by Hakånson (1980) to evaluate the ecological hazard effect resulted from toxic pollutants in sediments, has been widely applied to assess the environmental risk of heavy metal(loid)s in soil (Zhang et al. 2019; Ke et al. 2017; Suresh et al. 2012). The PER/ is calculated using the formula (3) (Zhang et al. 2019).

$$
\text { PERI }=\sum_{i=1}^{n} E_{r}^{i}=\sum_{i=1}^{n} T_{r}^{i} \times C_{f}^{i}=\sum_{i=1}^{n} T_{r}^{i} \times \frac{c_{i}^{i}}{c_{b}^{i}}
$$


where $C_{s}{ }^{i}$ represents the determined value of heavy metal(loid) $i$ in the soil, while $C_{b}{ }^{i}$ represents the corresponding reference value (CNEMC 1990). $T_{r}^{i}$ is the toxic response factor of different substance (As, $\mathrm{Cu}, \mathrm{Cr}, \mathrm{Mn}, \mathrm{Ni}, \mathrm{Pb}, \mathrm{V}$, and $\mathrm{Zn}$ are 10, 5, 2, 1, 6, 5, 2, and 1, respectively) (Yuan et al. 2014; Lu et al. 2014b). $E_{r}^{i}$ is the potential ecological risk index of heavy metal(loid) $i$ while $P E R /$ is the comprehensive potential ecological risk index. The evaluation criteria for $E_{r}^{i}$ and $P E R /$ are listed in Table S4 (Supplementary Materials) (Yuan et al. 2014; Lu et al. 2014b).

\section{Statistical analysis methods of data}

Descriptive statistical analysis, Pearson correlation analysis, cluster analysis (CA) and principal component analysis (PCA) were conducted using the commercial statistics software package SPSS version 21.0 for Windows (IBM Company, Chicago, USA). Descriptive statistics of heavy metal(loid) contents in the farmland soil samples, including minimum (Min), maximum (Max), mean, standard deviation (SD), coefficient of variation (CV), skewness and kurtosis, were applied to analyze the content characteristics of heavy metal(loid)s in the farmland soil. Pearson correlation analysis, CA and PCA, the extensively used multivariate statistical analysis methods in pollution studies (Wang et al. 2019; Zhang et al. 2019; Ke et al. 2017; Pan et al. 2017; Lu et al. 2014a), were adopted to determine the relationships among heavy metal(loid)s and to identify their possible sources combining their content characteristics and pollution levels in the farmland soils near the zinc smelter.

\section{Results And Discussion}

\section{Heavy metal(loid) contents}

The determination results of the heavy metal(loid)s contents from the farmland soil samples together with the reference value (CNEMC 1990) are presented in Table 1. As shown in Table 1, the mean contents of $\mathrm{As}, \mathrm{Cu}, \mathrm{Cr}, \mathrm{Pb}, \mathrm{Mn}, \mathrm{Ni}, \mathrm{V}$, and $\mathrm{Zn}$ were 17.3, 39.5, 135.7, 143.3, 571.1, 35.8, 82.4, and $771.9 \mathrm{mg} \mathrm{kg}^{-1}$, respectively. Except for $\mathrm{Mn}$, the mean contents of $\mathrm{As}, \mathrm{Cu}, \mathrm{Cr}, \mathrm{Pb}, \mathrm{Ni}, \mathrm{V}$, and $\mathrm{Zn}$ were above their corresponding reference value, which were $1.6,1.8,2.2,6.7,1.2,1.2$, and 11.1 times the reference, respectively. The coefficient of variation (CV), the ratio of the standard deviation and the mean, is a statistical measure reflecting the variability of the observed value. In general, a CV $\leq 20 \%$ indicates low variability, a CV range of $21-50 \%$ indicates moderate variability, a CV range of $51-100 \%$ shows high variability, and a CV $>100 \%$ is regarded as very high variability (Pan et al. 2017; Phil-Eze 2010). Table 1 shows that the contents of heavy metal(loid)s determined in the farmland soil around the zinc smelter presented different variance. The contents of $\mathrm{Zn}, \mathrm{Pb}$, and $\mathrm{Cu}$ presented high variability $(51 \%<\mathrm{CV} \leq$ $100 \%$, the content of As presented moderate variability, and the other heavy metal(loid)s showed low variability. The large $\mathrm{CV}$ values of $\mathrm{Zn}, \mathrm{Pb}, \mathrm{Cu}$, and As reveal their heterogeneity in the farmland soil around the zinc smelter, which might demonstrate the existence and impact of anthropogenic sources (Pan et al. 2020, 2017; Karim et al. 2014). 
Kurtosis and skewness values indicated whether the concentrations of the studied heavy metal(loid)s follow a normal distribution. The kurtosis values of $\mathrm{As}, \mathrm{Cu}, \mathrm{Pb}$, and $\mathrm{Zn}$ are 2.7, 3.7, 1.8, and 2.5 respectively, showing that these four elements deviated from the normal distribution. The absolute kurtosis values of $\mathrm{Cr}, \mathrm{Mn}, \mathrm{Ni}$, and $\mathrm{V}$ are less than 1 , indicating that their contents in the soil samples were close to the normal distribution. Skewness values of 9.9, 15.9, 5.1, and 8.8 further indicated that $\mathrm{As}, \mathrm{Cu}$, $\mathrm{Pb}$, and $\mathrm{Zn}$ were skewed positively towards the higher concentration. While, the skewness values of $\mathrm{Cr}$, $\mathrm{Mn}, \mathrm{Ni}$, and $\mathrm{V}$ are close to $\mathrm{O}$, showing that the content distribution of these four elements was relatively uniform.

Fig. 2 shows that the investigated heavy metal(loid)s in the farmland soils of three plots have diverse variation features. The contents of $\mathrm{As}, \mathrm{Cu}, \mathrm{Pb}$, and $\mathrm{Zn}$ in the farmland soils of three plots have remarkable difference, while the content diversities of $\mathrm{Cr}, \mathrm{Mn}, \mathrm{Ni}$, and $\mathrm{V}$ in the farmland soils of three plots are indistinct. The mean contents of $\mathrm{As}, \mathrm{Cu}, \mathrm{Pb}$, and $\mathrm{Zn}$ in the farmland soils of three plots presented plot $\mathrm{A}>$ plot $C>$ plot $B$. According to Chinese soil environmental quality-Risk control standard for soil contamination of agricultural land (GB 15618-2018) (MEE 2018), the contents of $\mathrm{Pb}$ in $67 \%$ soil samples of plot $A$ and $50 \%$ soil samples of plot $C$, and the contents of $Z n$ all soil samples of plot $A$ and plot $C$ are larger than their corresponding risk screening values for soil contamination of agricultural land of China, implying the soil environment and agricultural products may exist pollution risk of $\mathrm{Pb}$ and $\mathrm{Zn}$.

Fig. 3 shows that the contents of $\mathrm{As}, \mathrm{Cu}, \mathrm{Pb}, \mathrm{Zn}$, and $\mathrm{Ni}$ in the farmland soil samples from plot A present decreasing trend with the increase of the distance between the sampling site and the zinc smelter, while the contents of $\mathrm{Cr}, \mathrm{Mn}$, and $\mathrm{V}$ in the farmland soil have not distinct trend. The contents of $\mathrm{As}, \mathrm{Cu}, \mathrm{Pb}$, and Zn decreased $88 \%, 76 \%, 71 \%$, and $83 \%$ respectively and $\mathrm{Ni}$ contents declined $28 \%$ in the farmland soil with the distance of soil sampling site to the zinc smelter increasing from $100 \mathrm{~m}$ to $300 \mathrm{~m}$ (Fig. 3). Plot $A$ is situated in the downwind direction of the zinc smelter. Considering no other pollution sources existing in the vicinity of the zinc smelter, we think the aforementioned variation characteristics of heavy metal(loid)s content in the farmland of plot $A$ reflecting the impact of zinc-smelting activity on the contents of $\mathrm{As}, \mathrm{Cu}, \mathrm{Pb}, \mathrm{Zn}$, and $\mathrm{Ni}$.

\section{Pollution and ecological risk of heavy metal(loid)s}

The results of $P_{i}$ and NSPI are shown in Table 2 and Fig. 4. The determined heavy metal(loid)s presented pollution at different extent in three plots, except for $\mathrm{As}$ in plot B and $\mathrm{Mn}$ in plot $\mathrm{C}$. The mean $P_{i}$ values of $\mathrm{As}, \mathrm{Cu}, \mathrm{Pb}$, and $\mathrm{Zn}$ in the farmland soil decrease in the order of plot $\mathrm{A}>\operatorname{plot} \mathrm{C}>\operatorname{plot} \mathrm{B}$. Especially $\mathrm{Pb}$ and $\mathrm{Zn}$, their $P_{i}$ values are 10.31 and 15.92 in plot $\mathrm{A}$, and 6.80 and 14.64 in plot $\mathrm{C}$ respectively, presenting severe pollution. The pollution diversity of heavy metal(loid)s in three plots may be related with their position and terrain. Plot A is located in downwind of the zinc smelter and its terrain is higher than the zinc smelter. The special topography hinder the further diffusion of smoke and dust with heavy metal(loid) particles and promote pollutants sinking, which may be the cause of severe soil pollution in plot $A$. Plot $B$ is not in the dominant wind direction, and there are lush trees and vegetation between plot $B$ and the smelter. Plot $\mathrm{C}$ is situated in the east of the smelter (downwind) and its terrain is lower than the 
smelter. The diffusion of pollutants discharged from the smelter in plot $\mathrm{C}$ is easier than in plot A. Fig. 4 shows that the NSP/values of heavy metal(loid)s in the farmland soils from plot $\mathrm{B}$ are in range of 2-3 presenting moderate pollution, while which in the farmland soils from plot $A$ and plot $\mathrm{C}$ are all larger than 3 except sample $\mathrm{C} 3$ indicating serious pollution. The comprehensive pollution degree of heavy metal(loid)s in three plots decreases in the order of plot $\mathrm{A}>$ plot $\mathrm{C}>$ plot $\mathrm{B}$.

The computed results of $I_{\text {geo }}$ for elements in the farmland soil around zinc smelter of Shangluo are presented in Table 3 and Table S5 (Supplementary Materials). In plot A, the $I_{\text {geo }}$ of $\mathrm{Mn}$ and $\mathrm{V}$ are all below zero, indicating no pollution of these two metals in samples from plot A. Most of the $I_{\text {geo }}$ value of $\mathrm{Ni}$ are under zero, which indicated no pollution, except two $I_{\text {geo }}$ values 0.03 (A4) and 0.09 (A7) (Table S5 in Supplementary Materials) slightly greater than zero. The $I_{\text {geo }}$ value of As range from -0.44 (A3) to 1.66 (A7) which corresponded to level 0 of unpolluted to level 2 of moderately polluted. The mean $I_{\text {geo }}$ value of 0.31 indicated As is slightly polluted. As for $\mathrm{Cr}$, the $I_{\text {geo }}$ value of which range from 0.30 to 0.68 with the mean value of 0.55 , indicated $\mathrm{Cr}$ was slightly polluted in plot $\mathrm{A}$. The mean $I_{\text {geo }}$ value of $\mathrm{Cu}$ is 0.51 , which corresponded to level 1 of slightly polluted. Sample from A7 is an exception, the $I_{\text {geo }}$ value of which is 2.03 corresponded to level 3 of moderately severely polluted. $\mathrm{Pb}$ and $\mathrm{Zn}$ showed more accumulation in plot $\mathrm{A}$ as compared to other seven elements. The mean $I_{\text {geo }}$ value of $\mathrm{Pb}$ is 2.66 which corresponded to level 3 of moderately severely polluted. The max $I_{\text {geo }}$ value of 3.95 (A7) corresponded to level 4 of severely polluted. The mean $I_{\text {geo }}$ value of $\mathrm{Zn}$ is 3.12 which corresponded to level 4 of severely polluted. Sample from A7 was extremely polluted with the $I_{\text {geo }}$ value of 5.14.

In plot $\mathrm{B}$, the $I_{\text {geo }}$ of $\mathrm{As}, \mathrm{Mn}, \mathrm{Ni}$ and $\mathrm{V}$ are all below zero, which indicated no samples are polluted by these four elements in plot $\mathrm{B}$. The mean $I_{\text {geo }}$ value of $\mathrm{Cu}$ is -0.11 , corresponding to level 0 of unpolluted, but the $I_{\text {geo }}$ value 0.10 and 0.05 from $\mathrm{B} 5$ and $\mathrm{B} 8$ are two exceptions. As for $\mathrm{Cr}, \mathrm{Pb}$ and $\mathrm{Zn}$, the $I_{\text {geo }}$ of them are all between 0 and 1 , showed samples from plot $B$ were slightly polluted by these elements.

In plot $\mathrm{C}$, the $I_{\text {geo }}$ values of $\mathrm{Mn}, \mathrm{Ni}$ and $\mathrm{V}$ are all below zero, which indicated no samples are polluted by these elements in plot $\mathrm{C}$. For $\mathrm{As}, \mathrm{Cr}$ and $\mathrm{Cu}$, their mean $I_{\text {geo }}$ values are between 0 and 1 , indicating that these three elements corresponded to level 1 of slightly polluted. Samples from C2 and C3 were unpolluted with As. The $I_{\text {geo }}$ value of $\mathrm{Cr}$ has little change, the maximum and minimum values are 0.46 and 0.33 respectively. As for $\mathrm{Cu}$, the $I_{\text {geo }}$ value of samples from C1, C2, C3 and $\mathrm{C} 4$ are $<0$, corresponding to level 0 of unpolluted. The $I_{\text {geo }}$ value of samples from C5, C6, C7 and C8 are between 0 and 1 (Table S5 in Supplementary Materials), corresponding to level 1 of slightly polluted. Similar to plot $\mathrm{A}, \mathrm{Pb}$ and $\mathrm{Zn}$ are also accumulated obviously in plot $\mathrm{C}$. The $I_{\text {geo }}$ value of $\mathrm{Pb}$ ranged from 1.05 (C3) to 2.68 (C8) which corresponded to level 2 of moderately polluted and level 3 of moderately to severely polluted. The mean $I_{\text {geo }}$ value 2.06 of $\mathrm{Pb}$ indicated moderately polluted in plot $\mathrm{C}$. The mean $I_{\text {geo }}$ value of $\mathrm{Zn}$ is 3.15 which corresponded to level 4 of severely polluted. The same as $\mathrm{Pb}$, the minimum $I_{\text {geo }}$ value of $\mathrm{Zn} 1.74$ appears at C3 and maximum Igeo value 4.07 appears at C8. 
The $E_{r}^{i}$ values of heavy metal(loid)s in the farmland soils are shown in Fig. 5. It can been found from Fig. 5 , the $E_{r}^{i}$ values of $\mathrm{Cr}, \mathrm{Mn}, \mathrm{Ni}$, and $\mathrm{V}$ in soil samples and $\mathrm{Cu}$ in most soil samples (except soil sample $\mathrm{A} 7 \mathrm{in}$ plot A) are $<15$, indicating low ecological risk level. As and $Z n$ in some soil samples of plot $A$ and plot $C$ have moderate and considerable ecological risk. $\mathrm{Pb}$ in the farmland soils from three plots possesses different ecological risk levels, i.e. in plot A presenting considerable to high ecological risk, in plot B presenting low ecological risk, while in plot $\mathrm{C}$ presenting moderate to considerable ecological risk. The $P E R /$ values of heavy metal(loid)s determined in the farmland soil near the zinc smelter range from 43.5 to 261.5 with an mean of 83.5 , showing the investigated soils have wide ecological risk levels, i.e. low to high ecological risk. The comprehensive ecological risk levels of heavy metal(loid)s in the farmland soils of three plots are low in plot $\mathrm{B}$, moderate in plot $\mathrm{C}$ and considerable in plot $\mathrm{A}$. $\mathrm{Pb}$ is the main contributor of the comprehensive ecological risk, then are $\mathrm{As}, \mathrm{Cu}$ and $\mathrm{Zn}$, which respectively contributes $37.2 \%, 19.3 \%$, $11.7 \%$, and $11.3 \%$ to $P E R I$.

\section{Multivariate Statistical results and source identification}

\section{Pearson's correlation analysis results}

Studying the correlation between elements can predict whether the sources of heavy metal(loid)s are same owing to different heavy metal(loid)s in soil have different migration and enrichment trends. If there is a correlation between them, the source may be similar, otherwise the source may be different (Dong et al. 2019). The Pearson correlation analysis results of heavy metal(loid)s in the farmland soil around the zinc smelter are displayed in Table 4. Table 4 displays that there are very significantly positive correlations $(P<0.01)$ among $\mathrm{As}, \mathrm{Cu}, \mathrm{Pb}$, and $\mathrm{Zn}$, and the correlation between each other is highly correlated. Similarly, positive correlations $(P<0.01)$ were found among $\mathrm{Cr}, \mathrm{Mn}$, and $\mathrm{V}$. Different from the other seven elements, $\mathrm{Ni}$ appeared moderately positive correlation with $\mathrm{As}, \mathrm{Cu}$, and $\mathrm{Pb}(P<0.01)$. At the significant level of 0.05 , Ni has a positive correlation with $\mathrm{Cr}, \mathrm{Mn}, \mathrm{V}$, and $\mathrm{Zn}$, but the correlation degree is low.

To some extent, the correlation between heavy metal(loid) elements reflects the similarity of pollution degree or the similar sources of heavy metal(loid)s. The correlation coefficient analysis also suggested that $\mathrm{As}, \mathrm{Pb}, \mathrm{Cu}$, and $\mathrm{Zn}$ may have the same source or similar geochemical properties. $\mathrm{Pb}-\mathrm{Zn}$ minerals are often accompanied by heavy metal(loid) elements such as $\mathrm{Cu}$, As, etc., which are the main characteristic pollutants of nonferrous smelting industry (Félix et al. 2015; Tembo et al. 2006). In addition, the combustion of coal during metal smelting may be a source of As (Lu et al. 2009). The correlation coefficient analysis also indicated that $\mathrm{Cr}, \mathrm{Mn}$, and $\mathrm{V}$ may have the same source.

\section{PCA results}

Table 5 shows the PCA results of heavy metal(loid)s determined in the farmland soil around the zinc smelter. It can be seen from Table 5, two factors with the eigenvalues $>1$ were extracted in PCA, which explains $92.2 \%$ of the total variance. The contribution rate of the first factor is $52.9 \%$, and the factor loads of $\mathrm{As}, \mathrm{Cu}, \mathrm{Ni}, \mathrm{Pb}$, and $\mathrm{Zn}$ are $0.982,0.961,0.679,0.972$, and 0.960 , respectively. The second factor 
explains $39.3 \%$ of the total variance and the factor loads of $\mathrm{Cr}, \mathrm{Mn}, \mathrm{V}$, and $\mathrm{Ni}$ are $0.956,0.950,0.974$, and 0.575 , respectively.

\section{CA results}

The CA results are shown in Fig. 6. As, $\mathrm{Cu}, \mathrm{Pb}, \mathrm{Zn}$, and $\mathrm{Ni}$ are the first category, which can be further divided into 2 sub-clusters, i.e., As- $\mathrm{Zn}-\mathrm{Pb}-\mathrm{Cu}$ and $\mathrm{Ni}$. $\mathrm{Cr}, \mathrm{V}$, and $\mathrm{Mn}$ are the second category. The result of cluster analysis is consistent with that of PCA.

\section{Heavy metal(loid) source identification}

Eight elements were divided into two groups based on the multivariate statistical analysis results together with their contents characteristics in the soil. The first group of elements are $\mathrm{As}, \mathrm{Cu}, \mathrm{Pb}, \mathrm{Zn}$, and $\mathrm{Ni}$. In Pearson's correlation analysis and PCA, these five elements have strong positive correlation, and are clustered together in cluster analysis. Combining the content characteristics and pollution levels of As, $\mathrm{Cu}, \mathrm{Pb}, \mathrm{Zn}$, and $\mathrm{Ni}$ in the soil, as well as their spatial variation trend in the downwind farmland of the zinc smelter, we think these elements in the farmland soil around the zinc smelter mainly came from the emission of zinc smelter. It should be noted that there is a certain difference between As and other four metals. The results of correlation analysis and PCA indicate that As in the farmland soil has other source yet.

The second group is composed of $\mathrm{Cr}, \mathrm{Mn}$, and $\mathrm{V}$. Compared with the first group of elements, the coefficients of variation of these three metals are comparatively small, indicating that their contents variations in the investigated soil samples are minor. Combined the results of multivariate statistical analysis and pollution assessment, as well as the field investigation, we consider that these metals in the farmland soil mainly originated from natural source. As has a certain correlation with $\mathrm{Cr}$, $\mathrm{Mn}$, and $\mathrm{V}$ in correlation analysis and PCA, showing that As in the farmland soil partly originated from natural source.

\section{Conclusions}

The farmland soils around a zinc smelter in Shangluo, the water source area of the Mid-route of SouthNorth Water Transfer Project of China have elevated heavy metal(loid)s except Mn. The zinc-smelting activity influenced the heavy metal(loid)s content, particularly $\mathrm{Zn}$ and $\mathrm{Pb}$, in the surrounding farmland soil. The contents of $\mathrm{Zn}$ in the farmland soil of the northwest and the east of the zinc smelter and the contents of $\mathrm{Pb}$ in more than half of soil samples of the northwest and the east of the zinc smelter exceed the risk screening values for soil contamination of agricultural land of China. The determined heavy metal(loid)s in the farmland soil presented diverse pollution level and spatial diversity. Zn was moderately to severely polluted, $\mathrm{Pb}$ was moderately polluted, $\mathrm{Cr}$ and $\mathrm{Cu}$ were slightly polluted, and other elements were unpolluted. The comprehensive pollution of heavy metal(loid)s in the farmland were extreme as a whole. The comprehensive ecological risk of heavy metal(loid)s in the farmland soils was moderate as a whole, which mainly contributed by $\mathrm{Pb}$, then $\mathrm{As}, \mathrm{Cu}$, and $\mathrm{Zn}$. $\mathrm{As}, \mathrm{Cu}, \mathrm{Pb}$, and $\mathrm{Zn}$ in the soil mainly originated from the emission of the zinc smelter. $\mathrm{Cr}, \mathrm{Mn}$, and $\mathrm{V}$ primarily came from natural 
source. $\mathrm{Ni}$ in the farmland soil mainly derived the emission of the zinc smelter, partly came from natural source. According to this research, the local government should pay attention to the elevated $\mathrm{As}, \mathrm{Cu}, \mathrm{Pb}$, $\mathrm{Zn}$, and $\mathrm{Ni}$ content, particularly $\mathrm{Zn}$ and $\mathrm{Pb}$, in the farmland soil caused by zinc-smelting activities and strengthen the cooperative monitoring of heavy metal(loid)s in farmland and agricultural products, as well as pollutant emission monitoring and control. In addition to, the environmental impact and risk of other mining and smelting activities in the water source area should be investigated in the future.

\section{Declarations}

Acknowledgements The study was supported by the National Natural Science Foundation of China (No. 41271510), the Research and Development Key Project of Shaanxi Province (2020SF-433), Shaanxi Province Natural Science Foundation Research Project (Youth Talent Project) (2014JM2-4040) and Science and Technology Research Project of Shangluo University (SK2014-01-24).

Authors' contribution SZ: field sampling, methodology, statistical analysis, writing-original draft. XL: funding acquisition, conceptualization, writing-review \& editing.

Competing interests The authors declare no competing interest with respect to the publication and authorship of this paper.

\section{References}

Akopyan K, Petrosyan V, Grigoryan R, Melkomian DM (2018) Assessment of residential soil contamination with arsenic and lead in mining and smelting towns of northern Armenia. $\mathrm{J}$ Geochem Explor 184:97-109

Baltas H, Sirin M, Gökbayrak E, Ozcelik AE (2020) A case study on pollution and a human health risk assessment of heavy metals in agricultural soils around Sinop province, Turkey. Chemosphere 241:125015

Bhatti SS, Kumar V, Sambyal V, Singh J, Nagpal AK (2018) Comparative analysis of tissue compartmentalized heavy metal uptake by common forage crop: A field experiment. Catena 60:185-193

Chakraborty S, Man T, Paulette L, Deb S, Li B, Weindorf DC, Frazier M (2017) Rapid assessment of smelter/mining soil contamination via portable X-ray fluorescence spectrometry and indicator kriging. Geoderma 306:108-119

Chen X, Lu X, Li LY, Yang G (2013) Spatial distribution and contamination assessment of heavy metals in urban topsoil from inside the Xi'an second ringroad, NW China. Environ Earth Sci 68:1979-1988

Csavina J, Field J, Taylor MP, Gao S, Landázuri A, Betterton EA, Sáez AE (2012) A review on the importance of metals and metalloids in atmospheric dust and aerosol from mining operations. Sci Total Environ 433:58-73 
CNEMC (China National Environmental Monitoring Centre) (1990) The Background Values of Elements in Chinese Soils. Environmental Science Press of China, Beijing (in Chinese)

Dong B, Zhang R, Gan Y, Cai L, Freidenreich A, Wang K, Guo T, Wang H (2019) Multiple methods for the identification of heavy metal sources in cropland soils from a resource-based region. Sci Total Environ 651:3127-3138

Duodu GO, Goonetilleke A, Ayoko GA (2016) Comparison of pollution indices for the assessment of heavy metal in Brisbane River sediment. Environ Pollut 219:1077-1091

Ettler V (2016) Soil contamination near non-ferrous metal smelters: A review. Appl Geochem 64:56-74

Félix OI, Csavina J, Field J, Rine KP, Sáez AE, Betterton EA (2015) Use of lead isotopes to identify sources of metal and metalloid contaminants in atmospheric aerosol from mining operations. Chemosphere $122: 219-226$

Ghayoraneh M, Qishlaqi A (2017) Concentration, distribution and speciation of toxic metals in soils along a transect around a Zn/Pb smelter in the northwest of Iran. J Geochem Explor 180:1-14

Hakånson L (1980) An Ecological Risk Index for Aquatic Pollution Control-A Sedimentological Approach. Water Res 14:975-1001

Jiang Y, Guo X (2019) Multivariate and geostatistical analysis of heavy metal pollution from different sources among farmlands in the Poyang Lake region, China. J Soils Sediments 19:2472-2484

Kang M-J, Kwon YK, Yu S, Lee P-K, Park H-S, Song N (2019) Assessment of Zn pollution sources and apportionment in agricultural soils impacted by a Zn smelter in South Korea. J Hazard Mater 364:475-87

Karim Z, Qureshi BA, Mumtaz M, Qureshi S (2014) Heavy metal content in urban soils as an indicator of anthropogenic and natural influences on landscape of Karachi-A multivariate spatio-temporal analysis. Ecol Indic 42:20-31

Ke X, Gui S, Huang H, Zhang H, Wang C, Guo W (2017) Ecological risk assessment and source identification for heavy metals in surface sediment from the Liaohe River protected area, China. Chemosphere 175:473-481

Kř́bek B, Nyambe I, Majer V, Knésl I, Mihaljevič M, Ettler V, Vaněk A, Penížek V, Sracek O (2019) Soil contamination near the Kabwe $\mathrm{Pb}-\mathrm{Zn}$ smelter in Zambia: Environmental impacts and remediation measures proposal. J Geochem Explor 197:159-73

Kumar V, Sharma A, Kaur P, Sidhu GPS, Bali AS, Bhardwaj R, Thukral AK, Cerda A (2019) Pollution assessment of heavy metals in soils of India and ecological risk assessment: A state-of-the-art. Chemosphere 216:449-462 
Lee P-K, Kang M-J, Jeong Y $-J$, Kwon YK, Yu S (2020) Lead isotopes combined with geochemical and mineralogical analyses for source identification of arsenic in agricultural soils surrounding a zinc smelter. J Hazard Mater 382:121044

Li X, Li Z, Lin C, Bi X, Liu L, Feng X, Zhang H, Chen J, Wu T (2018) Health risks of heavy metal exposure through vegetable consumption near a large-scale $\mathrm{Pb} / \mathrm{Zn}$ smelter in central China. Ecotox Environ Safe 161:99-110

Li Y, Wang S, Nan Z, Zang F, Sun H, Zhang Q, Huang W, Bao L (2019) Accumulation, fractionation and health risk assessment of fluoride and heavy metals in soil-crop systems in northwest China. Sci Total Environ 663:307-314

Li Y, Wang S, Daniel P, Xu S, Nan Z, Zang F, Zhang Q (2017) Accumulation and interaction of fluoride and cadmium in the soil-wheat plant system from the wastewater irrigated soil of an oasis region in northwest China. Sci Total Environ 595:344-351

Li Z, Feng X, Li G, Bi X, Sun G, Zhu J, Qin H, Wang J (2011) Mercury and other metal and metalloid soil contamination near a $\mathrm{Pb} / \mathrm{Zn}$ smelter in east Hunan province, China. Appl Geochem 26:160-166

Liu B, Ai S, Zhang W, Huang D, Zhang Y (2017) Assessment of the bioavailability, bioaccessibility and transfer of heavy metals in the soil-grain-human systems near a mining and smelting area in NW China. Sci Total Environ 609:822-829

Lu X, Zhang X, Li LY, Chen H (2014a) Assessment of metals pollution and health risk in dust from nursery schools in Xi'an, China. Environ Res 128:27-34

Lu X, Wu X, Wang Y, Chen H, Gao P, Fu Y (2014b) Risk assessment of toxic metals in street dust from a medium-sized industrial city of China. Ecotox Environ Safe 106:154-163

Lu X, Li LY, Wang L, Lei K, Huang J, Zhai Y (2009) Contamination assessment of mercury and arsenic in roadway dust from Baoji, China. Atmos Environ 43:2489-2496

MEE (Ministry of Ecology and Environment) (2018) Soil environmental quality-Risk control standard for soil contamination of agricultural land (GB 15618-2018). Environmental Science Press of China, Beijing (in Chinese)

Müller G (1969) Index of geo accumulation in sediments of the Rhine River. Geo J 2(3):108-118

Pan H, Lu X, Lei K (2020) Contamination identification of trace metals in roadway dust of a typical mountains county in the Three Gorges Reservoir Region, China, and its relationships with socioeconomic factors. Sustainability 12:5624

Pan H, Lu X, Lei K (2017) A comprehensive analysis of heavy metals in urban road dust of Xi'an, China: Contamination, source apportionment and spatial distribution. Sci Total Environ 609:1361-1369 
Peng H, Chen Y, Weng L, Ma J, Ma Y, Li Y, Islam MS (2019) Comparisons of heavy metal input inventory in agricultural soils in North and South China: A review. Sci Total Environ 660:776-786

Phil-Eze PO (2010) Variability of soil properties related to vegetation cover in a tropical rainforest landscape. J Geogr Reg Plann 3:177-184

Shen F, Liao R, Ali A, Mahar A, Guo D, Li R, Sun X, Awasthi MK, Wang Q, Zhang Z (2017) Spatial distribution and risk assessment of heavy metals in soil near a $\mathrm{Pb} / \mathrm{Zn}$ smelter in Feng County, China. Ecotox Environ Safe 139:254-262

Shiel AE, Weis D, Orians KJ (2010) Evaluation of zinc, cadmium and lead isotope fractionation during smelting and refining. Sci Total Environ 408:2357-2368

Suresh G, Sutharsan P, Ramasamy V, Venkatachalapathy R (2012) Assessment of spatial distribution and potential ecological risk of the heavy metals in relation to granulometric contents of Veeranam lake sediments, India. Ecotox Environ Safe 84:117-124

Tembo BD, Sichilongo K, Cernak J (2006) Distribution of copper, lead, cadmium and zinc concentrations in soils around Kabwe town in Zambia. Chemosphere 63:497-501

Wang J, Su J, Li Z, Liu B, Cheng G, Jiang Y, Li Y, Zhou S, Yuan W (2019) Source apportionment of heavy metal and their health risks in soil-dustfall-plant system nearby a typical non-ferrous metal mining area of Tongling, Eastern China. Environ Pollut 254:113089

Wang X, He M, Xie J, Xi J, Lu X (2010) Heavy metal pollution of the world largest antimony mineaffected agricultural soils in Hunan province (China). J Soils Sediments 10:827-837

Wen H, Zhang Y, Cloquet C, Zhu C, Fan H, Luo C (2015) Tracing sources of pollution in soils from the Jinding $\mathrm{Pb}-\mathrm{Zn}$ mining district in China using cadmium and lead isotopes. Appl Geochem 52:147-54

Wu J, Margenot AJ, Wei X, Fan M, Zhang H, Best JL, Wu P, Chen F, Gao C (2020) Source apportionment of soil heavy metals in fluvial islands, Anhui section of the lower Yangtze River: comparison of APCS-MLR and PMF. J Soils Sediments 20:3380-3393

Yang Y, Chang AC, Wang ME, Chen WP, Peng C (2018) Assessing cadmium exposure risks of vegetables with plant uptake factor and soil property. Environ Pollut 238:263-269

Yuan G-L, Sun T-H, Han P, Li J, Lang X-X (2014) Source identification and ecological risk assessment of heavy metals in topsoil using environmental geochemical mapping: Typical urban renewal area in Beijing, China. J Geochem Explor 136:40-47

Zhang Z, Zhang N, Li H, Lu Y, Wang Q, Yang Z (2019) Risk assessment, spatial distribution, and source identification of heavy metal(loid)s in paddy soils along the Zijiang River basin, in Hunan Province, China. J Soils Sediments 19:4042-4051 
Zhang J, Wang Y, Liu J, Liu Q, Zhou Q (2016) Multivariate and geostatistical analysis of the sources and spatial distribution of heavy metals in agricultural soil in Gongzhuling, Northeast China. J Soils Sediments 16:634-644

Zhao X, He B, Wu H, Zheng G, Ma X, Liang J, Li P, Fan Q (2020) A comprehensive investigation of hazardous elements contamination in mining and smelting-impacted soils and sediments. Ecotox Environ Safe 192:110320

Zhou J, Du B, Liu H, Cui H, Zhang W, Fan X, Cui J, Zhou J (2020) The bioavailability and contribution of the newly deposited heavy metals(copper and lead) from atmosphere to rice (Oryza sativa L.). J Hazard Mater 384:121285

Zhuang S, Lu X (2020) Environmental risk evaluation and source identification of heavy metal(loid)s in agricultural soil of Shangdan valley, Northwest China. Sustainability 12:5806

\section{Tables}

Table 1 Descriptive statistics of heavy metal(loid) concentrations $\left(\mathrm{mg} \mathrm{kg}^{-1}\right)$ in soil around the zinc smelter.

\begin{tabular}{|c|c|c|c|c|c|c|c|c|}
\hline Element & As & $\mathrm{Cr}$ & $\mathrm{Cu}$ & $\mathrm{Mn}$ & $\mathrm{Ni}$ & $\mathrm{Pb}$ & V & $\mathrm{Zn}$ \\
\hline Max & 51.3 & 150.1 & 130.8 & 632.1 & 45.9 & 495.5 & 94.3 & 3678.7 \\
\hline Min & 9.7 & 115.1 & 20.4 & 416.8 & 29.7 & 50.1 & 63.5 & 123.1 \\
\hline Mean & 17.3 & 135.7 & 39.5 & 571.1 & 35.8 & 143.3 & 82.4 & 771.9 \\
\hline SD & 8.6 & 10.1 & 21.0 & 58.1 & 4.2 & 100.6 & 8.2 & 752.9 \\
\hline CV(\%) & 49.7 & 7.4 & 53.2 & 10.2 & 11.7 & 70.2 & 10.0 & 97.5 \\
\hline Kurtosis & 2.7 & -0.5 & 3.7 & -0.9 & 0.8 & 1.8 & -0.5 & 2.5 \\
\hline Skewness & 9.9 & -0.9 & 15.9 & 0.3 & 0.3 & 5.1 & -0.8 & 8.8 \\
\hline Reference $^{a}$ & 11.1 & 62.5 & 21.4 & 557.0 & 28.8 & 21.4 & 66.9 & 69.4 \\
\hline
\end{tabular}

Notes: ${ }^{a}$ CNEMC 1990. SD: standard deviation; CV: coefficient of variace.

Table 2 The $P_{i}$ of heavy metal(loid)s in the soil samples. 


\begin{tabular}{|c|c|c|c|c|c|c|}
\hline \multirow[t]{2}{*}{ Element } & \multicolumn{2}{|c|}{ Plot A } & \multicolumn{2}{|c|}{ Plot B } & \multicolumn{2}{|c|}{ Plot C } \\
\hline & Mean & Range & Mean & Range & Mean & Range \\
\hline As & 2.02 & $1.10-4.62$ & 0.93 & $0.87-0.99$ & 1.67 & $1.14-2.25$ \\
\hline $\mathrm{Cr}$ & 2.21 & $1.84-2.40$ & 2.29 & $2.18-2.40$ & 2.01 & $1.89-2.06$ \\
\hline $\mathrm{Cu}$ & 2.36 & $1.65-6.11$ & 1.40 & $1.26-1.60$ & 1.71 & $0.95-2.86$ \\
\hline $\mathrm{Mn}$ & 1.02 & $0.75-1.12$ & 1.11 & $1.09-1.13$ & 0.94 & $0.89-0.99$ \\
\hline $\mathrm{Ni}$ & 1.39 & $1.14-1.59$ & 1.20 & $1.10-1.26$ & 1.13 & $1.03-1.23$ \\
\hline $\mathrm{Pb}$ & 10.31 & $6.17-23.15$ & 2.52 & $2.34-2.86$ & 6.80 & $3.10-10.91$ \\
\hline V & 1.24 & $0.95-1.36$ & 1.35 & $1.30-1.41$ & 1.11 & $1.09-1.15$ \\
\hline $\mathrm{Zn}$ & 15.92 & $7.82-53.01$ & 2.22 & $1.77-2.68$ & 14.64 & $5.02-25.16$ \\
\hline
\end{tabular}

Table 3 The $I_{\text {geo }}$ of heavy metal(loid) in farmland soil around Shangluo zinc smelter.

\begin{tabular}{|llllllllll|}
\hline Element & As & $\mathrm{Cr}$ & $\mathrm{Cu}$ & $\mathrm{Mn}$ & $\mathrm{Ni}$ & $\mathrm{Pb}$ & $\mathrm{V}$ & $\mathrm{Zn}$ \\
\hline Plot A & & & & & & & & \\
Max & 1.62 & 0.68 & 2.03 & -0.42 & 0.09 & 3.95 & -0.14 & 5.14 \\
Min & -0.44 & 0.30 & 0.14 & -1.00 & -0.39 & 2.04 & -0.66 & 2.38 \\
Mean & 0.31 & 0.55 & 0.51 & -0.56 & -0.12 & 2.66 & -0.28 & 3.12 \\
Plot B & & & & & & & & \\
Max & -0.60 & 0.68 & 0.10 & -0.40 & -0.25 & 0.93 & -0.09 & 0.84 \\
Min & -0.78 & 0.54 & -0.25 & -0.47 & -0.45 & 0.64 & -0.23 & 0.24 \\
Mean & -0.68 & 0.61 & -0.11 & -0.43 & -0.32 & 0.75 & -0.16 & 0.55 \\
Plot C & & & & & & & & \\
Max & 0.58 & 0.46 & 0.93 & -0.60 & -0.28 & 2.86 & -0.38 & 4.07 \\
\hline Min & -0.40 & 0.33 & -0.65 & -0.76 & -0.54 & 1.05 & -0.46 & 1.74 \\
\hline Mean & 0.13 & 0.42 & 0.12 & -0.67 & -0.42 & 2.06 & -0.43 & 3.15 \\
\hline
\end{tabular}

Table 4 Pearson's correlation matrix between the concentration of heavy metal(loid)s in soil around the smelter. 


\begin{tabular}{|lllllllll|}
\hline Metal & $\mathrm{As}$ & $\mathrm{Cr}$ & $\mathrm{Cu}$ & $\mathrm{Mn}$ & $\mathrm{Ni}$ & $\mathrm{Pb}$ & $\mathrm{V}$ & $\mathrm{Zn}$ \\
\hline $\mathrm{As}$ & 1 & -0.076 & $0.924^{\star \star}$ & -0.039 & $0.606^{\star *}$ & $0.947^{\star \star}$ & -0.166 & $0.973^{\star *}$ \\
$\mathrm{Cr}$ & 0.716 & 1 & 0.019 & $0.860^{\star \star}$ & $0.480^{\star}$ & -0.070 & $0.930^{\star \star}$ & -0.230 \\
$\mathrm{Cu}$ & 0.000 & 0.927 & 1 & 0.029 & $0.621^{\star \star}$ & $0.905^{\star \star}$ & -0.046 & $0.925^{\star \star}$ \\
\hline $\mathrm{Mn}$ & 0.853 & 0.000 & 0.891 & 1 & $0.476^{\star}$ & -0.125 & $0.919^{\star *}$ & -0.180 \\
\hline $\mathrm{Ni}$ & 0.001 & 0.015 & 0.001 & 0.016 & 1 & $0.627^{\star \star}$ & $0.438^{\star}$ & $0.463^{\star}$ \\
\hline $\mathrm{Pb}$ & 0.000 & 0.741 & 0.000 & 0.552 & 0.001 & 1 & -0.188 & $0.930^{\star *}$ \\
\hline $\mathrm{V}$ & 0.428 & 0.000 & 0.828 & 0.000 & 0.028 & 0.368 & 1 & -0.312 \\
\hline $\mathrm{Zn}$ & 0.000 & 0.269 & 0.000 & 0.389 & 0.020 & 0.000 & 0.130 & 1 \\
\hline
\end{tabular}

The right upper part is correlation coefficient; the left lower part is significant level.

${ }^{* *}$ Correlation is significant at $\mathrm{P} \otimes 0.01$ (two-tailed).

* Correlation is significant at $\mathrm{P} \otimes 0.05$ (two-tailed).

Table 5 Rotated component matrix for data of soil around the zinc smelter.

\begin{tabular}{|llll|}
\hline \multirow{2}{*}{ Elements } & \multicolumn{2}{l}{ Component } & \multirow{2}{*}{ Communality } \\
\cline { 2 - 3 } & 1 & 2 & \\
$\mathrm{ys}$ & $\mathbf{0 . 9 8 2}$ & -0.046 & 0.967 \\
$\mathrm{Cr}$ & -0.033 & $\mathbf{0 . 9 5 6}$ & 0.916 \\
\hline $\mathrm{Cu}$ & $\mathbf{0 . 9 6 1}$ & 0.050 & 0.925 \\
$\mathrm{Mn}$ & -0.023 & $\mathbf{0 . 9 5 0}$ & 0.902 \\
\hline $\mathrm{Ni}$ & $\mathbf{0 . 6 7 9}$ & $\mathbf{0 . 5 7 5}$ & 0.791 \\
\hline $\mathrm{Pb}$ & $\mathbf{0 . 9 7 2}$ & -0.071 & 0.950 \\
\hline $\mathrm{V}$ & -0.122 & $\mathbf{0 . 9 7 4}$ & 0.963 \\
\hline $\mathrm{Zn}$ & $\mathbf{0 . 9 6 0}$ & -0.208 & 0.965 \\
\hline Eigenvalue & 4.232 & 3.148 & \\
\hline \%of total expained variance & $52.9 \%$ & $39.3 \%$ & \\
\hline \%of cumulative expained variance & $52.9 \%$ & $92.2 \%$ & \\
\hline
\end{tabular}

Extraction method: Principal Component Analysis. 
Rotation method: Varimax with Kaiser normalization.

Rotation converged in 3 iterations.

\section{Figures}

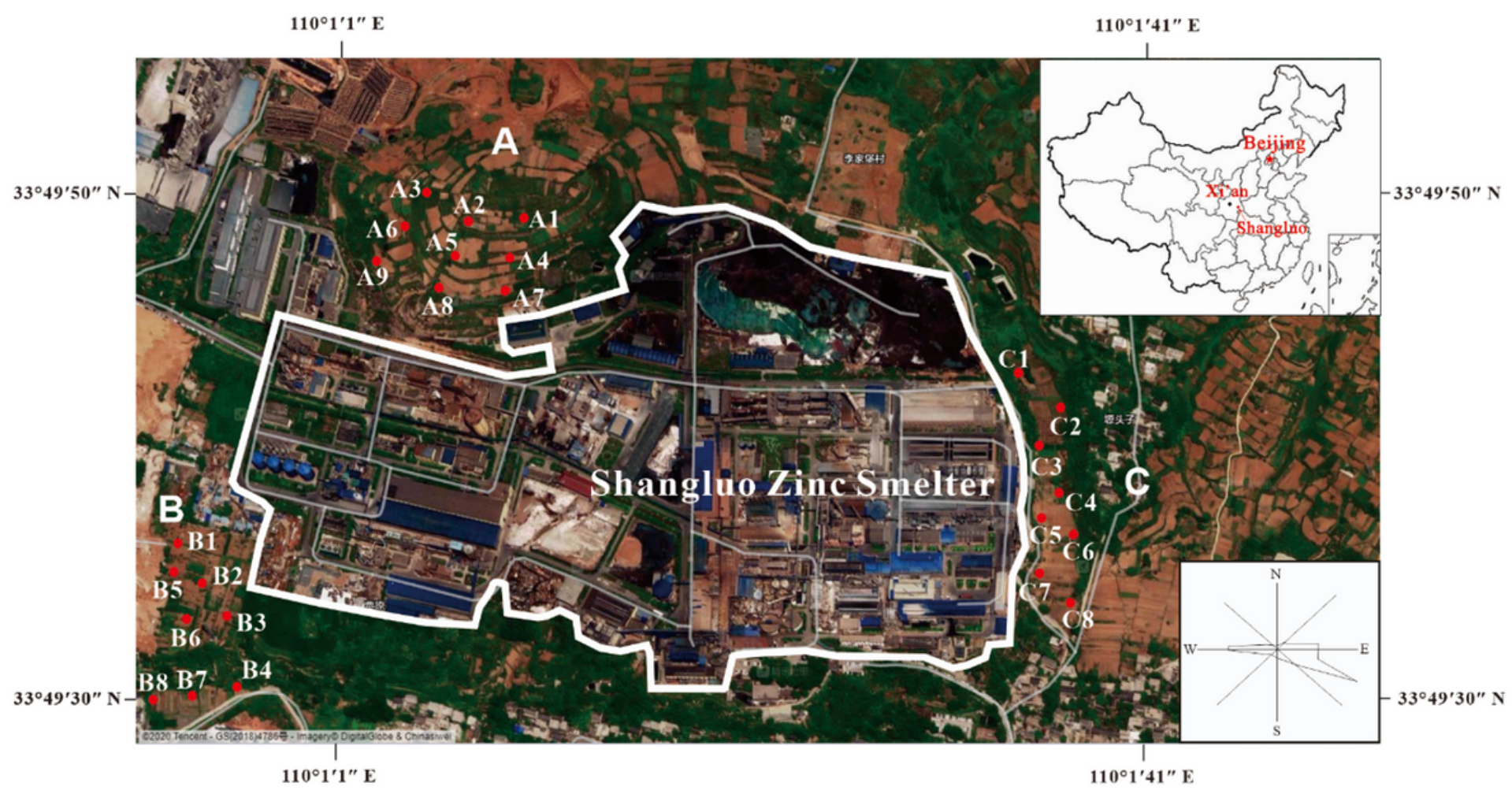

\section{Figure 1}

Location of the zinc smelter and soil sampling sites. Note: The designations employed and the presentation of the material on this map do not imply the expression of any opinion whatsoever on the part of Research Square concerning the legal status of any country, territory, city or area or of its authorities, or concerning the delimitation of its frontiers or boundaries. This map has been provided by the authors. 

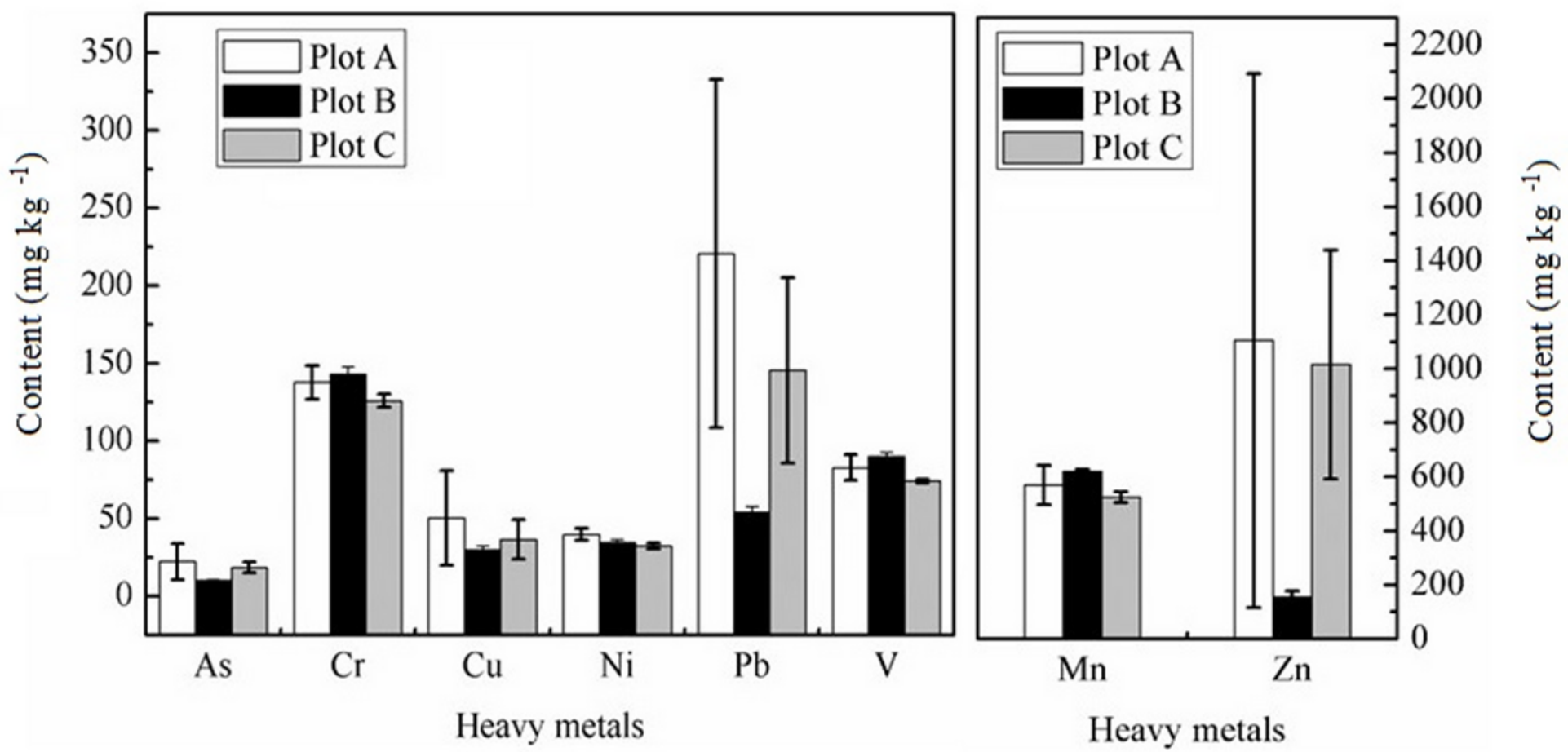

Figure 2

Heavy metal(loid) contents in the farmland soil of Plot A, Plot B and Plot C. 

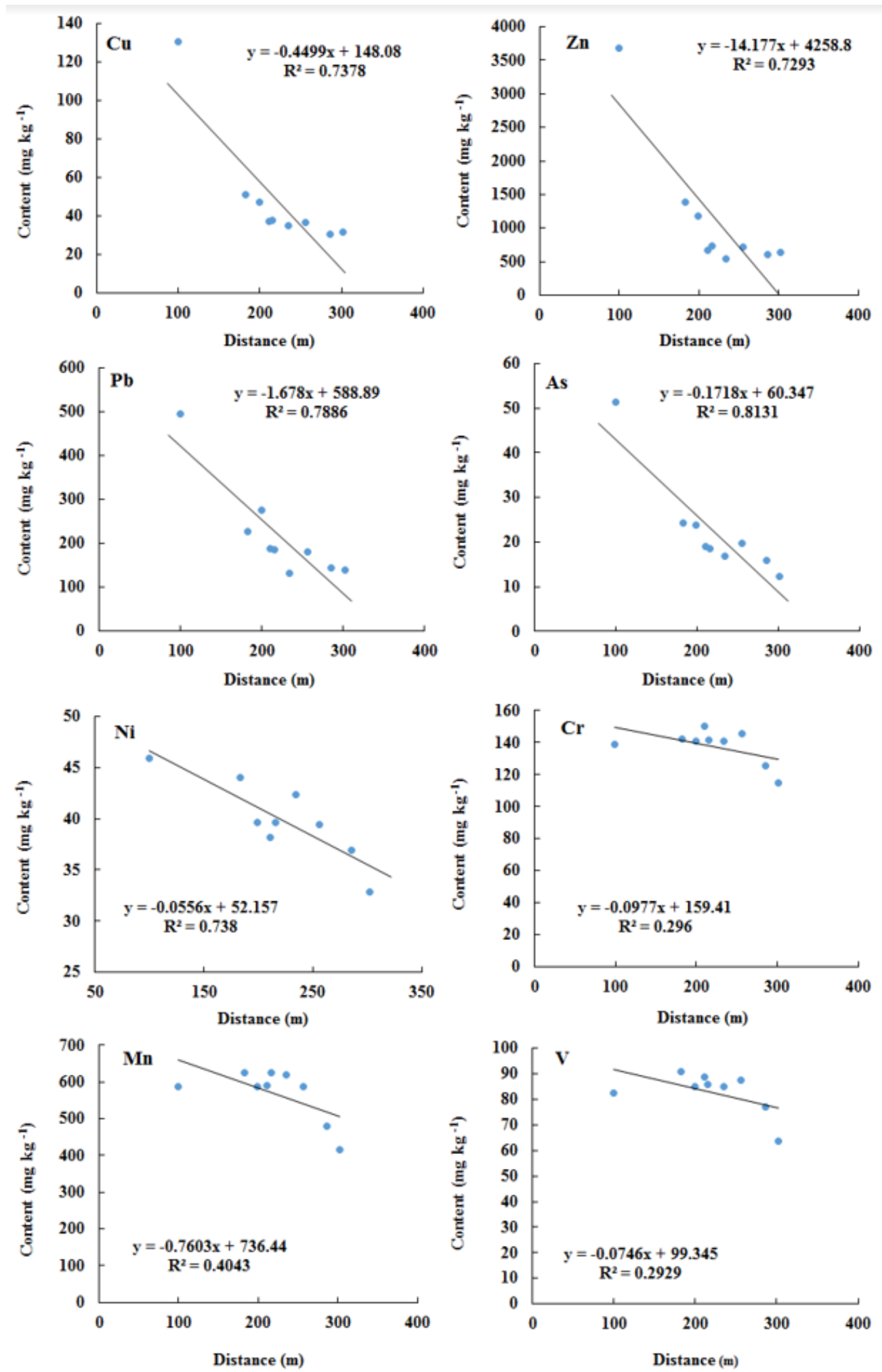

\section{Figure 3}

Relationship between heavy metal(loid) concentration and distance (Plot A). 


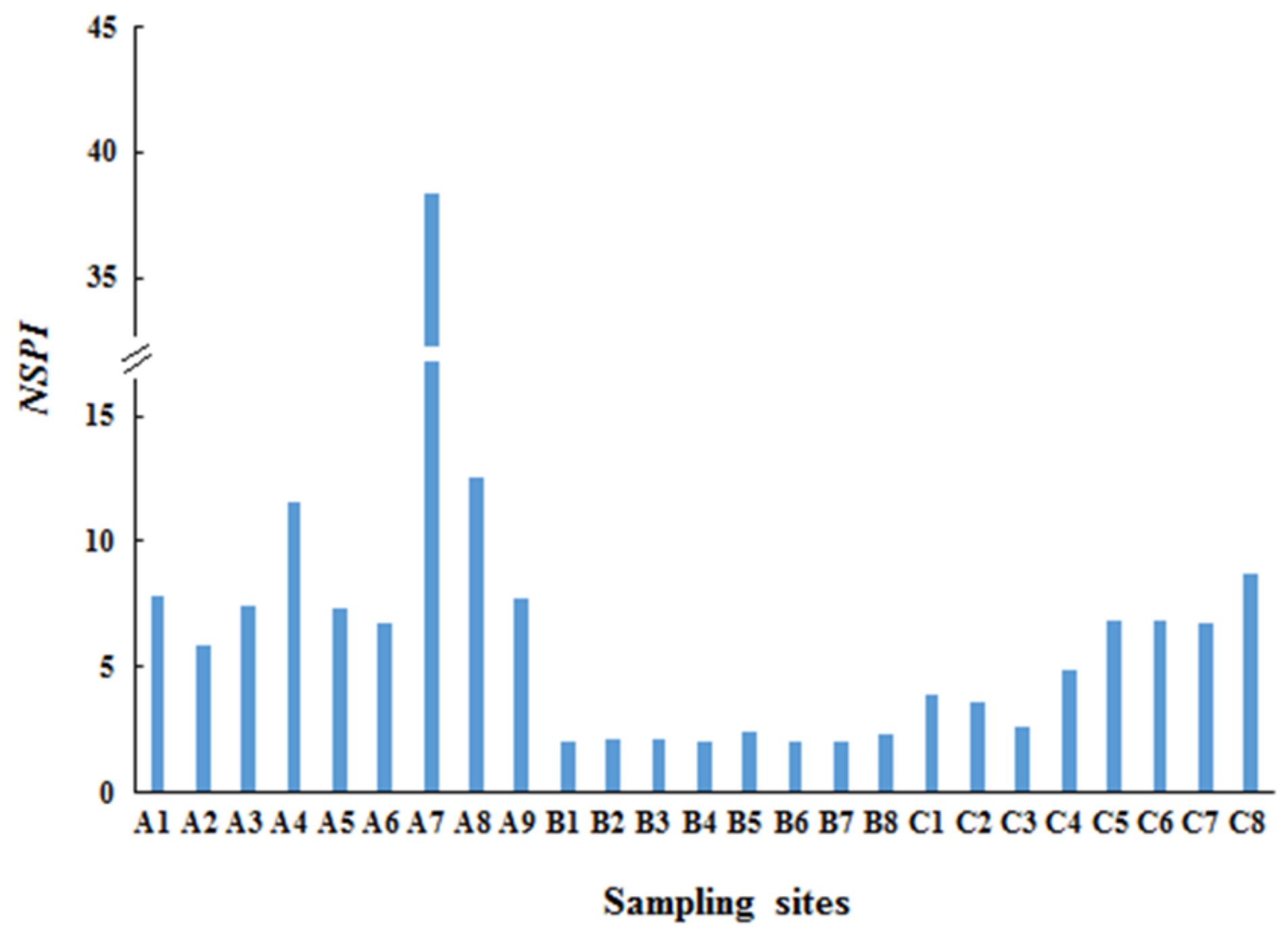

Figure 4

The NSPI values of heavy metal(loid)s in the farmland soils. 


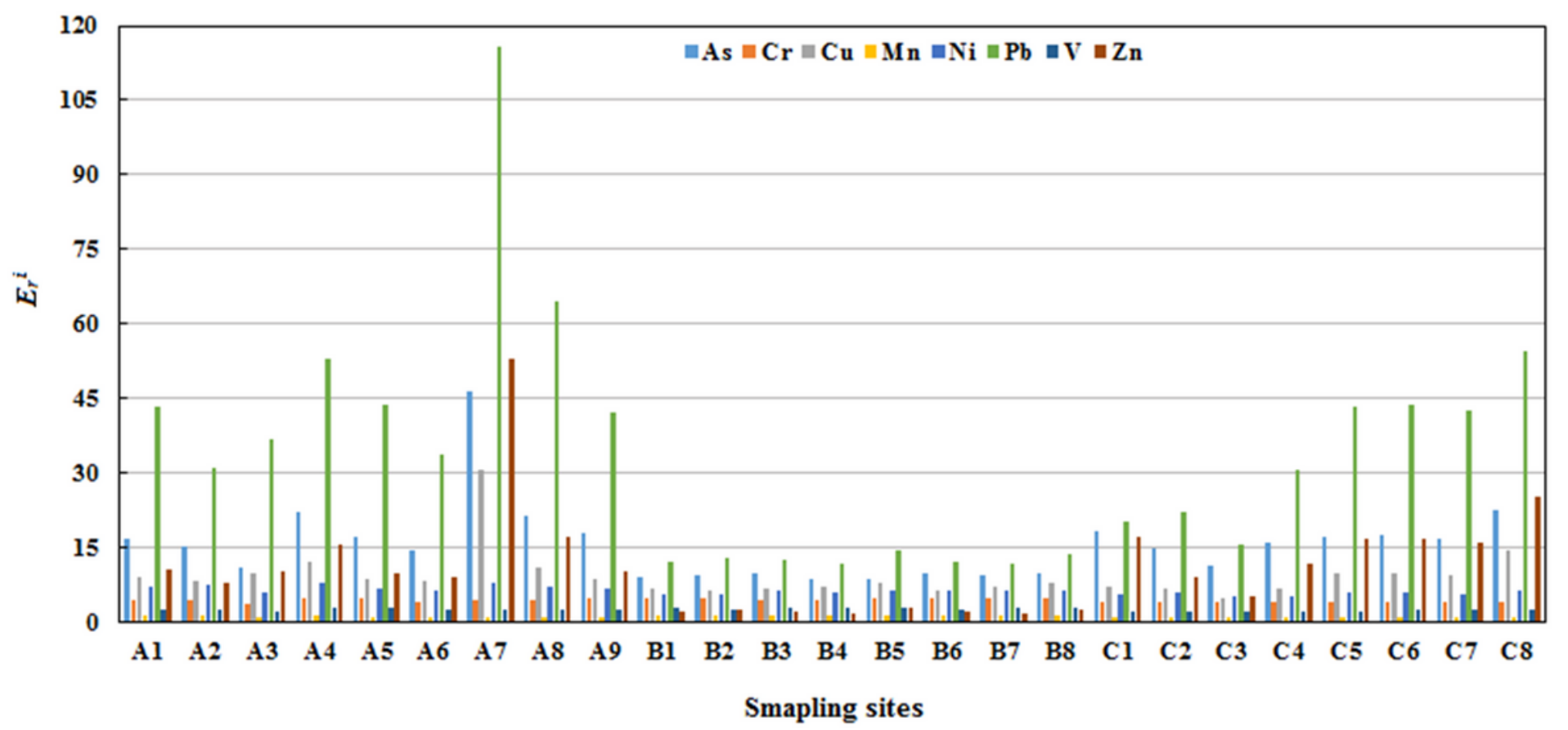

Figure 5

The $\mathrm{Er}^{\wedge} \mathrm{i}$ values of heavy metal(loid)s in the farmland soils. 


\section{Rescaled distance cluster combine}

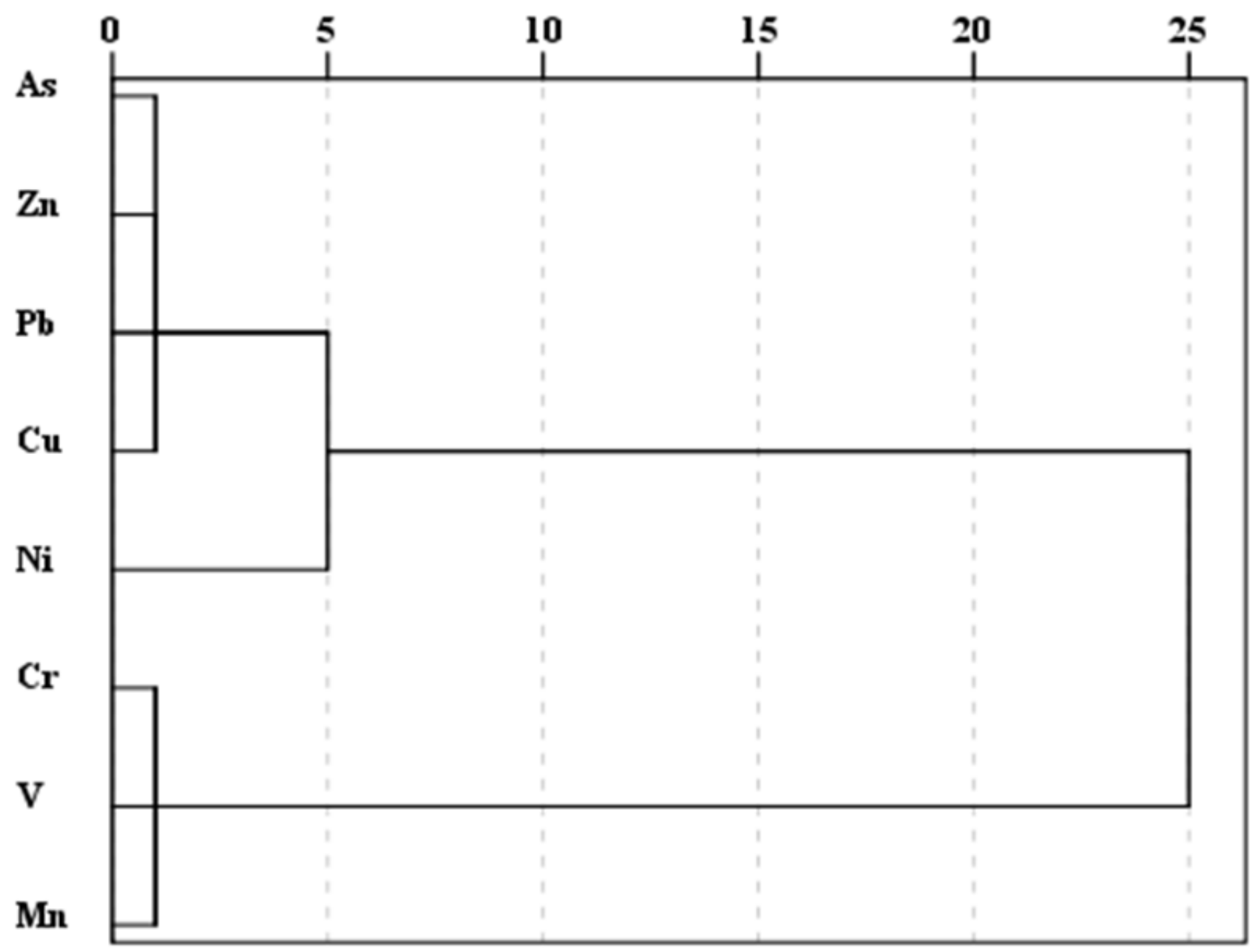

Figure 6

Dendrogram results from Ward method of hierarchical cluster analysis for 8 elements

\section{Supplementary Files}

This is a list of supplementary files associated with this preprint. Click to download.

- SupplementaryMaterials20210315.docx 